\title{
Artigos
}

\section{Las sobrevivientes. Fotos, dictadura, Museos y subversión. El caso de Córdoba}

\author{
Irina Mendiara ${ }^{1}$ \\ Mariana Sirimarco ${ }^{2}$
}

\section{Resumen}

Qué imágenes han servido en la Argentina para hacer visible la desaparición? No por supuesto de la desaparición como tal, sino de la desaparición en tanto práctica que condensa el secuestro, la tortura, la detención ilegal, el asesinato, su ocultamiento. Este trabajo busca proponer, para esta pregunta, un nuevo corpus de imágenes: las fotografías de prensa que retrataron, en su época, los museos de la subversión que existieron durante la última dictadura, y que fueron desmantelados antes de la restauración democrática. Hace pie para ello en un corpus específico -un puñado de fotos que sobrevivieron al “Museo de la Lucha contra la Subversión” de Córdoba-, indagando en su origen y su trayectoria. Este texto es así un intento por reponer la ejecución y el derrotero de esas imágenes, y un modo de contestar, finalmente, la pregunta del principio. ¿Cómo, estas imágenes, pueden considerarse fotos de la desaparición?

\section{Palabras clave}

Fotografía. Museo de la subversión. Desaparición.

\begin{abstract}
Which are the images that have been used in Argentina to make visible the disappearance? Not obviously the disappearance as such, but the disappearance as a practice implying kidnapping, torture, illegal detention, killing, and its concealment. This paper aims to propose, to this question, a new corpus of images: the press photographs that covered, in the time, the museums of terrorism that operated during the last dictatorship, and that were dismantled before the democratic restoration. It focuses in a specific corpus -some photographs of the "Museum of the Battle against Terrorism" in Córdoba-, looking to interrogate its origin and trajectory. This paper is therefore an attempt to recover the taking and the course of that images, and a way of eventually
\end{abstract}

\footnotetext{
1 Licenciada en Antropología (Universidad de Buenos Aires, Argentina). Email imendiara@gmail.com.

2 Doutora em Antropologia pela Universidad de Buenos Aires. E-mail: maikenas@yahoo.com.ar.
} 
answering the question of the beginning. How might these images be considered photographs of the disappearance?

\section{Keywords}

Photographs. Museum of terrorism. Disappearance.

\section{Resumo}

Quais imagens serviram, na Argentina, para tornar visível o desaparecimento? Não o desaparecimento como tal, senão o desaparecimento como prática que condensa sequestros, torturas, detenções ilegais, assassinatos, encobrimentos. Este trabalho busca propor, para isso, um novo corpo de imagens: as fotografias jornalísticas dos museus de subversão que existiram durante a última ditadura, e que foram desmantelados antes da restauração da democracia. Focaliza para isso em um corpo específico -as fotos que sobreviveram ao "Museu da Luta contra a Subversão" em Córdoba-, investigando sua origem e trajetória. Este texto é então uma tentativa de recuperar a execução e a trajetória de essas imagens, e uma forma de finalmente responder a questão do começo. Porque essas imagens podem ser consideradas fotografias do desaparecimento?

\section{Palavras chave}

Fotografia. Museu da subversão. Desaparecimento.

Son las fotos las que perduran. No los museos. Ellas son las supervivientes DIDI-HUBERMAN, "Imágenes pese a todo..."

\section{Fotos y Museos. Una introducción}

En un texto de 2014, Claudia Feld se pregunta qué fotos pueden considerarse fotos de la desaparición. ${ }^{3}$ Habla, por supuesto, de la desaparición de personas durante la última dictadura cívico-militar y de los centros clandestinos de detención que fueron parte vital de esa maquinaria. La pregunta es obligada en función de una verdad anterior: no contamos, en nuestro país, con imágenes

\footnotetext{
${ }^{3}$ La alusión refiere a las fotos en tanto documentos probatorios de esta práctica. La categoría no engloba a aquellas fotografías que buscan recrear y/o representar la experiencia del terrorismo de estado, como las obras "Treintamil", "Secuela" (ambas de Fernando Gutiérrez) o "Desapariciones" (de Helen Zout). Para una profundización en torno a esta línea, ver especialmente Fortuny 2014.
} 
documentales de los procesos mismos que han provocado la muerte o la desaparición de estas personas -ni fotografías de las condiciones del cautiverio, ni de la tortura, ni de los vuelos de la muerte, por poner en unas pocas palabras ejemplos evidentes. No hay fotografías que nos permitan ver esa dimensión de la atrocidad (LANGLAND, 2005).

¿Qué imágenes, entonces, han servido en la Argentina para hacer visible la desaparición? ¿Qué imágenes han servido como documento probatorio? No por supuesto de la desaparición como tal - por otro lado materialmente inasible -, sino de la desaparición en tanto práctica que condensa una sumatoria de eventos mayormente concatenados: el secuestro, la tortura, la detención ilegal, el asesinato, su borramiento. ${ }^{4}$

Tenemos, de esa práctica, algún puñado de fotos ya célebres. Se trata siempre de fotos desplazadas. Fotos que atestiguan a las personas como víctimas, o a los lugares -ya vacíos- donde éstas lo fueron (FELD, 2010). La de Léonie Duquet y Alice Domon, por ejemplo, monjas francesas retenidas en la ESMA ${ }^{5}$ y obligadas a posar en sus sótanos bajo una bandera de Montoneros, en una burda estrategia de los marinos por desviar las responsabilidades de su secuestro ante la presión del gobierno francés. ${ }^{6} \mathrm{O}$ la de Thelma Dorothy Jara de Cabezas en un bar al que había sido llevada -puesta en escena, bien vestida y con peinado de peluquería- desde la misma ESMA (donde estaba secuestrada desde hacía tres meses), para hablar en la revista "Para Ti" de su hijo desaparecido y criticar a las Madres de Plaza de Mayo. ${ }^{7} \mathrm{O}$ las fotos de detenidos y represores que, paciente y arriesgadamente, fue sacando Víctor Basterra sobreviviente de la ESMA- entre sus ropas, cada vez que le permitían abandonar momentáneamente el predio. ${ }^{8} \mathrm{O}$ hasta la imagen que el fotógrafo Enrique Shore sacó, comisionado por la Conadep, ${ }^{9}$ de la mano de un ex-

\footnotetext{
${ }^{4}$ Aludimos, con el término desaparición, a su carácter de práctica clandestina y no, necesariamente, a las formas particulares de su desenlace (los desaparecidos).

${ }^{5}$ Escuela de Mecánica de la Armada. En su predio funcionó el centro clandestino de detención más importante del país.

6 Ver por ejemplo: https://www.pagina12.com.ar/diario/elpais/1-55806-2005-08-30.html. Consultado el 15/08/2021.

7 Ver por ejemplo: http://www.archivoinfojus.gob.ar/nacionales/el-fotografo-de-para-ti-queretrato-a-la-mujer-secuestrada-en-la-esma-2453.html. Consultado el 11/08/2021.

${ }^{8}$ Ver por ejemplo: http://www.laretaguardia.com.ar/2015/10/victor-basterra-el-primer-eslabonde-la.html

${ }^{9}$ Comisión Nacional sobre la Desaparición de Personas. Fue creada en 1983, con el retorno a la democracia, para investigar las violaciones a los derechos humanos cometidas durante la dictadura.
} 
detenido alumbrando con su encendedor una pared vacía: en ella aun podía verse la inscripción que había grabado ("Dios mío, ayúdame") cuando lo habían tenido ahí detenido. ${ }^{10}$

¿Qué fotos -aun en su desplazamiento- pueden considerarse fotos de la desaparición? Desde la perspectiva que acabamos de exponer, creemos que la pregunta alberga todavía respuestas no exploradas. Y que si ampliamos el ángulo de visión de la práctica de la desaparición por fuera de los límites formales del centro clandestino, abrimos la posibilidad de abarcar nuevos conjuntos de fotos-documento relevantes, y en estrecho vínculo aún con esos centros. Este trabajo busca proponer, para este campo, un nuevo corpus de imágenes que se desprende de la variedad de fotografías de prensa de la época que nos permiten asomarnos a los museos de la subversión que existieron durante la última dictadura, y que hoy ya no existen. No por el paso del tiempo y su desgaste; no existen porque fueron desmantelados, destruidos y finalmente negados. ${ }^{11}$ ¿Cuáles fueron estos museos? ¿Qué fotografías se conservan de ellos? ¿Por qué sostenemos que este acervo fotográfico bien puede ser llamado a convocar, también, el campo de las fotos de la desaparición?

Hacer esta propuesta inteligible requiere responder a estas preguntas. Comencemos diciendo que, salvo un par de excepciones, ${ }^{12}$ el asunto de los museos contra la subversión siempre fue una historia escrita en nota al pie. La información sobre ellos, como cabe esperar de un poder criminal que buscó eliminar toda prueba de su accionar, ${ }^{13}$ es escasa y fragmentaria. Es mucho aun, por ende, lo que nos falta conocer de estos espacios. ¿Cuáles fueron entonces estos museos? En el compendio oficial se señalan al menos cuatro. ${ }^{14}$ Uno inaugurado en 1976 y que funcionó en la Jefatura de Policía de la ciudad de San Miguel de Tucumán. Otro inaugurado en 1978 en Campo de Mayo, provincia de Buenos Aires. Un tercero en la provincia de Córdoba, que funcionó a partir de 1980. Y un cuarto en el Regimiento de Infantería I de Patricios, en la ciudad

10 Ver por ejemplo: https://www.pagina12.com.ar/140706-el-arte-del-vacio. Consultado el $22 / 08 / 2021$.

11 Volveremos sobre esto más adelante.

${ }^{12}$ Los textos que han abordado centralmente esta problemática son dos. El trabajo de Meloni González y Zurita (2018) se aboca al caso tucumano. El trabajo de Escudero (2020) se ocupa del caso cordobés y el caso bonaerense.

${ }^{13}$ Hacia el fin de la dictadura, el entonces presidente de facto general Reynaldo Bignone firmó un decreto reservado dictaminando la quema de todos los documentos vinculados a la represión.

14 Puede discutirse si el museo tucumano (Museo de la Policía), fue realmente un museo de la subversión o un típico museo histórico policial -tal vez con una sólo una sala dedicada a la temática. Para una profundización en torno a este debate y sus argumentos, ver Sirimarco 2019b. 
de Buenos Aires, que funcionó posiblemente en 1981 (SIRIMARCO, 2019b, 2020). ${ }^{15}$

1976, 1978, 1980, 1981. El énfasis en la cronología no es azaroso. Revela, por el contrario, una marca de autor. Revela a Antonio Domingo Bussi, uno de los militares más implicados en la represión ilegal estatal, quien organizó e inauguró -es la hipótesis- la totalidad de estos museos. ${ }^{16}$ Interventor de la provincia de Tucumán de marzo de 1976 a diciembre de 1977.17 Subjefe del Comando de Institutos Militares, en Campo de Mayo, de diciembre de 1977 a enero de 1979.18 Comandante del III Cuerpo de Ejército, con sede en Córdoba, de febrero a diciembre de $1980 .{ }^{19}$ Comandante del I Cuerpo de Ejército, con sede en Capital Federal, durante el último período de su carrera militar, de diciembre de 1980 a diciembre de 1981,20 antes de retirarse en enero de 1982. Bussi es, de estos espacios, el hilo conductor: los deja funcionando, a su paso, en todos los destinos en que reviste (SIRIMARCO, 2019b, 2020).

Se trata, en cada uno de ellos, de espacios museísticos destinados a celebrar la lucha contra la subversión. O más precisamente: de exponer -mediante la exhibición de objetos- el éxito de esa lucha. De narrar el discurso triunfalista a partir de banderas, organigramas, armas de fabricación casera, libros prohibidos o maniquíes vestidos de guerrilleros, en tanto los elementos mostrados se volvían la expresión material de la derrota del enemigo, la prueba tangible de la superioridad de las fuerzas estatales (ROBBEN, 2008; SALVI, 2012; NEMEC, 2019; SIRIMARCO, 2019b).

\footnotetext{
${ }^{15}$ La existencia de estos museos no invalida la de salas y/o espacios similares al interior de distintas fuerzas militares y de seguridad. De hecho, Diego Escolar reporta exhibiciones de corte semejante en el Museo Histórico de la Gendarmería Nacional para el 2001. Ver Escolar 2019, Sirimarco 2020.

16 “Cuando Bussi asumió ... yo todavía estaba en El Campito (...) Por lo primero que preguntó fue por el material secuestrado en los operativos, quería saber qué teníamos. Se ve que ya tenía en mente armar el museo de la subversión que hizo construir después (...) Tenía una afición por los "museos" e hizo construir tres dedicados a la "subversión" donde exponía libros, panfletos, objetos y armas incautados a los guerrilleros y maniquíes reproduciendo escenas de la "actividad guerrillera". El que habla es el ex sargento Ibañez; el testimonio se recoge en Almirón 1999.

${ }_{17}$ Ver: http://rig.tucuman.gov.ar/leyes/funcionarios.php?orden=1. Consultado el 08/08/2021.

18 Ver: http://www.saij.gob.ar/docs-

f/ediciones/libros/Estado_mayor_comando_institutos_militares.pdf. Consultado el 15/08/2021.

19 Entre enero y diciembre de 1979 Bussi fue director de la Gendarmería Nacional Argentina (http:// servicios.infoleg.gob.ar/infolegInternet/verNorma.do;jsessionid=4877E368D52767067CE 7895FF5456947?id=237212, consultado el 12/08/2021). Tal vez no sea casual lo referido por Escolar en la nota 13. Esta línea de indagación será motivo de una próxima profundización.
}

20 Ver: https://web.archive.org/web/20110226024400/http://www.abogarte.com.ar/garzon.htm. Consultado el 11/08/2021. 
De estos museos han quedado un puñado de testimonios y algunas huellas materiales. Ha quedado, también, una cantidad moderada de fotos. Una del museo tucumano, aparecida en el diario "La Gaceta" con motivo de su inauguración, donde vemos al jefe de policía local y el presidente de la Corte Suprema de Justicia escuchar las explicaciones de un oficial ante un escritorio lleno de aparatos de comunicaciones. ${ }^{21}$ Otras, que levantaron polvareda (por ser presumiblemente falsas), aparecidas tiempo después en el diario "El Cronista", donde sobre varios estantes y vitrinas reposan frascos con restos humanos pertenecientes a detenidos durante la lucha antisubversiva. ${ }^{22}$ Han quedado también muchas fotos de prensa del museo de Campo de Mayo: nos muestran autos destruidos, bombas "cazabobos", réplicas de "cárceles del pueblo", jarros usados en el monte por los subversivos, militares mostrando cómo se empuña un arma. ${ }^{23}$ Han quedado también cuatro fotos -ni una más, ni una menos- del museo cordobés, que serán el corpus de este trabajo. Hasta el día de hoy, no se conoce ninguna del museo porteño.

Hablamos, por supuesto, de las fotos con las que contamos. ${ }^{24} \mathrm{O}$ ni siquiera: hablamos de las fotos que conocemos. De aquellas a las que tuvimos acceso. Las que fueron publicadas en diarios y revistas de la época. Las que reposaban en sus archivos gráficos. Las que nos van llegando, como fragmentos de la existencia de ese espacio que fue. O las que -como las que conforman la columna vertebral de este trabajo- sobrevivieron gracias a fotógrafos individuales y al movimiento, en esta oportunidad favorable, de las casualidades. ${ }^{25}$

De esas cuatro fotos del museo cordobés -las sobrevivientes- habla este trabajo. Las recorta del corpus mayor por un simple motivo. No porque puedan, ellas solas, ser consideradas parte del acervo gráfico de la desaparición; de hecho, toda foto de los museos de la subversión ostenta este atributo. Las recorta porque su origen y su trayectoria permiten argumentar especialmente esta propuesta. No es un asunto de exclusividad sino de refuerzo: las fotos del museo de Córdoba se vuelven específicamente relevantes porque conocemos

\footnotetext{
${ }^{21}$ Diario La Gaceta, 30/12/1976, p.12.

${ }^{22}$ Diario El Cronista, 06/04/1992, p.7.

${ }^{23}$ Diario La Prensa, 05/10/1978, p.16; revista Gente, 26/10/1978, pp.64-70. Se conservan también fotos de archivo del diario Crónica (12/06/1980, Agencia Saporiti) y de la corresponsal extranjera Susan Meiselas para la agencia Magnum.

${ }^{24}$ Que de seguro la continuidad de la búsqueda en archivos (de prensa, estatales, particulares) va a seguir incrementando.

${ }^{25}$ Estas fotos existentes son, de hecho, el hilo conductor que permite recorrer los distintos museos de la subversión, en un libro de Mariana Sirimarco actualmente en preparación.
} 
de ellas su hechura. Permiten ser miradas no sólo como testimonio -como prueba de "la cosa existente", diría Benjamin (2013)- sino también como espacio de la experiencia del fotógrafo.

Las páginas que siguen nos hablan de la biografía de estas fotos. No sólo de cómo fueron tomadas -cuándo, por qué, cómo-, sino también del recorrido que siguieron, entre conservaciones, entregas, reposos y re-descubrimientos, de aquel día cordobés hasta nosotros. Porque ningún objeto es estático, sino una entidad dinámica y mutable, resultado de movimientos que han sedimentado o cristalizado en ellos y que los atraviesan de parte a parte con una trayectoria que viene de lejos y que continúa aun más allá (WARBURG, en DIDIHUBERMAN, 2009). De allí que estas fotos puedan ser vistas como un espacio de relaciones sociales sujeto a multiplicidad de ordenamientos $\mathrm{e}$ intervenciones.

Y de allí que interrogar su biografía no sea más que un modo de indagar el particular cruce que se da entre aquello que fue hecho para ser y aquello que se va volviendo (KOPYTOFF, 1991; APPADURAI, 1991; THOMAS, 1991; ALBERTI, 2005; SIRIMARCO, 2014, 2019a). Las páginas que siguen son un intento por reponer este derrotero, y un modo de contestar así, finalmente, la pregunta que atraviesa este trabajo. ¿Cómo, estas imágenes (las de Córdoba especialmente, pero todas en general) pueden considerarse fotos de la desaparición?

\section{Las Fotos del Museo de Córdoba. Historia de un azar ${ }^{26}$}

Conocí el Museo de Córdoba por fotos antes que por evidencias escritas. A finales de 2019, un contacto con Ezequiel Torres, por entonces coordinador de la Fototeca ARGRA, ${ }^{27}$ me llevó a Rafael Calviño, quien había sido, durante parte de la dictadura, reportero gráfico en la Editorial Atlántida. Rafael había sido enviado a cubrir una visita de Videla a Córdoba, y en ese contexto había sacado fotos de éste en el museo. De ese rollo (o de esos rollos) que había sacado, Rafael se quedó con cuatro fotos.

Cada una de ellas muestra tres elementos invariables. Uno, Antonio Domingo Bussi. Otro, Jorge Rafael Videla. El tercero, el museo: un espacio al

\footnotetext{
${ }^{26}$ Este apartado recupera el trabajo de campo y de archivo de Mariana Sirimarco. Cuando esto sucede, la escritura se marca en singular.

${ }^{27}$ La Fototeca ARGRA (Asociación de Reporteros Gráficos de la República Argentina) funciona, desde 2008, en al Archivo Nacional de la Memoria.
} 
parecer amplio, rodeado por cortinas pesadas (de un color indefinido tirando al rosa viejo) y esa típica profusión de objetos que en nada desentonan con aquellos retratados para el Museo de Campo de Mayo: un muñeco vestido de guerrillero, armas, una cárcel móvil, libros.

Las fotos llamaron mi atención; ninguna de las que conocía hasta ese momento, sobre estos museos, abundaba en gente. Tampoco ninguna dejaba ver al propio Bussi en medio de los espacios que -según entiendo- él mismo había organizado. Y sobre todo ninguna de las que había visto hasta el momento dejaba testimonio de la presencia de quién había negado, una y otra vez , la existencia de otro museo semejante. Me refiero a Videla y al museo de Campo de Mayo. ${ }^{28}$ Videla había desconocido su existencia en el marco de una causa judicial y, sin embargo, ahí estaba, mirando circunspecto el panel sobre "Intentos de Copamiento", capturado por el lente de Rafael Calviño, en un espacio distinto pero a todas luces igual en su contenido.

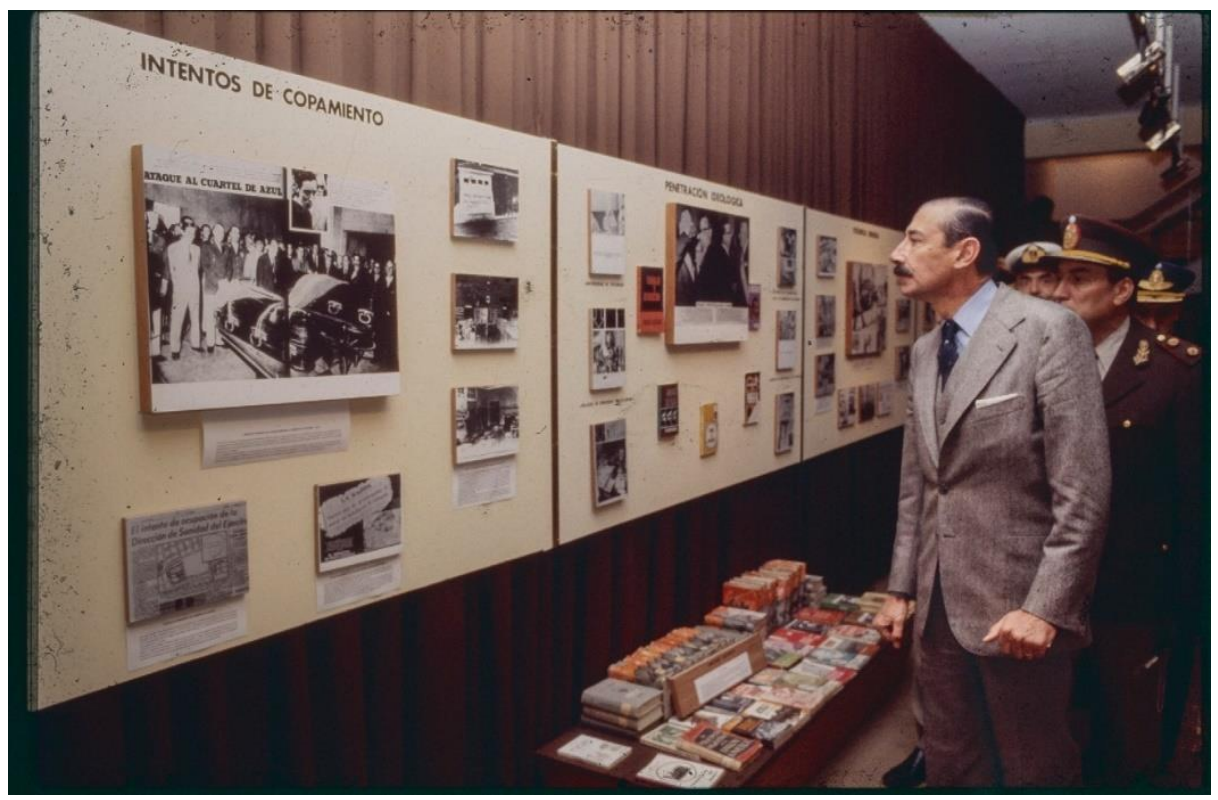

¿Cuándo fueron sacadas esas fotos? ¿Cuándo fue esa visita de Videla a Córdoba? Rafael no se acordaba:

28 "Violencia en los años 70: a 23 años de la muerte de un jefe guerrillero. Recuerdos del Jefe del ERP", Diario Clarin, 28/10/1999. En: https://www.clarin.com/politica/recuerdos-jefeerp_0_HJ3Dne0Ye.html. Consultado el 09/08/2021. 
No me acuerdo nada, en relación a fechas o lugares. Pero tengo el recuerdo de que fue brevísimo [el viaje]. Sí recuerdo que nos llevaban en alguna camioneta, o combi. Me acuerdo que él bajó ahí en helicóptero, que supongo que era un regimiento, o alguna cosa militar. Estuvo unos minutos ahí adentro, no más de veinte. Fue una situación muy corta, muy rápida. Bajó en helicóptero y se fue en helicóptero. Es más, tengo una foto, una especie de retrato, que saqué con un tele [objetivo], que se ve en la ventanilla del helicóptero a Videla. No se ve más nada. Y también tengo el recuerdo de algún otro acto, que no sé si era ahí mismo, que había como un mástil, con una bandera...

La trayectoria militar de Bussi hacía suponer que la visita debía haber sido en algún momento de 1980, pues era entonces que éste comandaba el III Cuerpo de Ejército con sede en esa provincia. La indagación de los archivos confirmó la suposición. Videla había visitado la provincia de Córdoba durante dos días, de la mañana del lunes 4 al martes 5 de agosto de 1980. La noticia había empezado a tener espacio en el diario "La Voz del Interior" desde al menos cinco días antes. ${ }^{29}$ Dentro de las actividades planeadas ya se especificaba, con antelación y para el primer día a las 19h, una visita al Comando del III Cuerpo de Ejército, donde rendiría "homenaje a los caídos en la lucha contra la subversión" y haría "una exposición ante jefes y oficiales de la Guarnición Militar Córdoba". ${ }^{30}$ La información se desplegaría, en el diario, aunque brevemente, al día siguiente de esa visita:

En las últimas horas de la tarde, el presidente de la Nación, teniente general (RE) Jorge Rafael Videla visitó el Comando del III Cuerpo de Ejército, donde fue recibido por el titular de esa gran unidad de combate, general de división Antonio Domingo Bussi, en cuya compañía revistó los efectivos formados. Tras ello el jefe de estado, en compañía del general Bussi y de otros oficiales superiores, recorrió el museo de lucha contra la subversión, interiorizándose del material bibliográfico, fotografías, reproducciones, uniformes, etc., elementos todos que fueran secuestrados a las bandas subversivas en diversos procedimientos realizados por las fuerzas de seguridad. El presidente Videla fue informado de la procedencia de este material y prestó atención a la nómina de los caídos

\footnotetext{
29 "Rio Cuarto: primera etapa de la visita presidencial", en: La Voz del Interior, 31/07/1980, p.9.

30 "El primer mandatario dialogará en Córdoba con miembros de sectores representativos", en: $L a$ Voz del Interior, 02/08/1980, p.2. La misma información se repite en las ediciones del 04/08/1980 ("Videla iniciará hoy su visita a Córdoba", p.1; "A las 9 arribará a Córdoba el teniente general Videla", p.9) y del 05/08/1980 (“La primera jornada de Videla en Córdoba", p.1).
} 
en cumplimiento de su deber, en lucha contra la subversión. Posteriormente, el primer mandatario argentino se trasladó al Salón de Actos del III Cuerpo, donde efectuó una exposición. ${ }^{31}$

La nota, más bien un recorte de la nota central, venía con una foto. El lente había inmovilizado a Videla y a Bussi mirándose de frente, a unos pasos de distancia, con los brazos rígidos al costado del cuerpo. Bussi de uniforme militar. Videla con estricto traje de tres piezas que en el blanco y negro de la impresión del diario podía pasar por celeste (pero que las fotos de Rafael Calviño revelan como gris). Al fondo se alcanzan a ver unos oficiales, tal vez también funcionarios. El granulado de la imagen no deja adivinar si ya están en el Salón de Actos o todavía en el museo.

Museo que, por supuesto, existía desde antes. Más precisamente, desde el 20 de junio de 1980, cuando había sido inaugurado, en el marco de los festejos por el día de la bandera. El "Museo de la lucha contra la Subversión", tal su nombre, había sido creado con sólido fundamento: el de no permitir que los pueblos olviden su pasado e hipotequen con ello su porvenir. "Este museo demuestra -recoge su acta de fundación- la superioridad del bien contra el mal, de los hijos del Señor contra los esbirros del príncipe de las tinieblas. Dios está con nosotros en la hora de la victoria, no se olviden jamás de estas páginas que marcan la agonía y muerte de la subversión en la selva tucumana y el coraje de los argentinos que la vencieron" (ESCUDERO, 2020, pp.190-191):32

A poco de arribar a nuestra ciudad, en la sede del Comando del Tercer Cuerpo de Ejército, el comandante en jefe del Ejército, teniente general Leopoldo Fortunato Galtieri presidió el acto inaugural del museo de la Lucha contra la Subversión. Estuvieron presentes las más altas autoridades civiles y militares de la provincia como así también el provicario castrense monseñor Victorio Bonamin quien hizo una invocación religiosa y bendijo las instalaciones. La muestra, de carácter permanente contiene diversos elementos secuestrados a los grupos terroristas, como fotografías que muestran algunas de las acciones cometidas y sus graves secuelas, bibliografía extremista, reproducciones en escala de cárceles del pueblo y una réplica de la cárcel móvil en la cual se asesinó al teniente coronel Ibarzábal. Se explicó al periodismo que con

\footnotetext{
31 "Videla en el Tercer Cuerpo", en: La Voz del Interior, 05/08/1980, p.9.

${ }^{32}$ La cita de Escudero referencia lo aparecido en una nota de El Pueblo, el 22/06/1980.
} 
este museo lo que se persigue es mostrar al país las atrocidades de una acción inhumana para que no se olvide, de la dura etapa que ha vivido. ${ }^{33}$

La lectura de la nota me reveló que las fotos de Rafael Calviño no eran, como yo creía, las únicas que había de ese museo. Porque encima de la nota había una imagen. Y en la imagen, a pesar del granulado, se dejaban ver Galtieri y Bonamin en primer plano, uno caminando delante del otro, insignias militares y aditamentos de sotana en pleno foco. Y detrás de ellos se veía otra gente. Y más atrás, y a pesar del fondo borroso de esa foto impresa, se dejaban adivinar unos paneles informativos recortados sobre una oscuridad sólida que no podía ser otra cosa que las cortinas pesadas de color indefinido.

Comprobé, con la siguiente nota revisada, que el museo permanente del III Cuerpo pronto se había transformado -al menos presumiblemente- en museo itinerante. Bien pronto, a decir verdad: inaugurado a finales de junio, ya a finales de agosto se había echado a rodar. ${ }^{34}$ Re-bautizado "Museo Móvil de la Lucha contra la Subversión", su nuevo destino ambulante había sido iniciado en los predios de la Exposición Rural en el campo La Perla. ${ }^{35}$

$\mathrm{Y}$ ahora ya no eran cinco las fotos, sino seis. Porque la nota que celebraba las buenas nuevas venía con otra imagen, borrosa ésta también, pero inequívoca: en un fondo de hombres de uniforme mirando cosas, el perfil en primer plano de otro hombre uniformado mirando armas.

El museo móvil viajaba rápido. Un mes después, para finales de septiembre, estaba en Tucumán:

San Miguel de Tucumán (Télam) - El Comando del Tercer Cuerpo de Ejército con asiento en Córdoba, presentó un stand móvil referido a la lucha contra la subversión en la muestra agrícola ganadera industrial y comercial "Expo Tucumán 80", que quedó inaugurada en el predio de la Sociedad Rural de esta provincia. ${ }^{36}$

En la oportunidad, luego de la recepción de las autoridades entre las que se encontraba el gobernador de la provincia, general de brigada (R) Lino

\footnotetext{
33 "Museo de la Lucha contra la Subversión", en: La Voz del Interior, 21/06/1980, p.9.

34 Tal vez porque el sitio del emplazamiento no garantizaba demasiadas visitas por fuera del consumo interno y/u oficial. "No se detenga. El centinela abrirá fuego", rezaba un cartel en la ruta adyacente al predio.

35 “Museo Móvil de la Lucha contra la Subversión”, en: La Voz del Interior, 31/08/1980, p.11.

${ }^{36}$ La estrecha relación entre la dictadura y la Sociedad Rural Argentina ha sido largamente referida. Será interesante profundizar, a futuro, las tramas concretas que vincularon a este museo móvil con las muestras y/o exposiciones realizadas en sus predios.
} 
Domingo Montiel Forzano, el comandante de la Quinta Brigada Julio César Ruiz y el presidente de la Sociedad Rural local, Dermidio, Martínez Zabalía, el mayor Leonardo José Lazzarano leyó un mensaje enviado por el comandante del III Cuerpo, general de división Antonio Domingo Bussi.

En uno de sus párrafos destaca el mensaje que "con la inauguración de este stand se procura rendir homenaje a todos los caídos en la lucha contra la subversión, civiles y militares, algunos mártires y otros héroes, cuya permanente recordación nos debe alentar y comprometer en una vigilia diaria para que nunca más la Patria quede expuesta a la acción disociadora de estos agentes del caos y la destrucción".

Señala también acerca del museo móvil que "pretende testimoniar a la comunidad tucumana, protagonista importante de nuestro acervo histórico, quiénes fueron y qué pretendieron hacer los delincuentes terroristas que un día, todavía no muy lejano, intentaron encaramarse en el poder, para desde allí socavar los pilares básicos de nuestra sociedad y trastocar el sistema de vida de los argentinos".

Luego de añadir que "además intenta quizás en un pantallazo demasiado rápido mostrar a nuestros conciudadanos el daño tremendo que estos mismos terroristas ocasionaron al patrimonio espiritual y material de la República", el mensaje del general Bussi, finaliza diciendo: "esperamos que este conocimiento público de hechos recientemente acaecidos sirva de sana recordación a todos aquellos compatriotas frágiles de memoria que hoy parecieran olvidar lo que ocurrió ayer mismo en el suelo patrio".

El stand, montado sobre un acoplado de grandes dimensiones es custodiado por soldados de llanura y monte ataviados con uniformes históricos. En el interior se muestran paneles con organigramas de las organizaciones terroristas, material impreso marxista y fotografías de actos de agitación social y operaciones en el monte. ${ }^{37}$

De seguro el museo móvil tuvo otros destinos, pero seguirlos sería, en el marco de este trabajo, bifurcarse demasiado. Nos demoramos en cambio en estos otros pasos previos, no con ánimo enciclopedista, sino con un objetivo más llano en mente. El de acercar contextos. Es decir, el de reponer una historia fáctica. Porque toda foto necesita una memoria, sobre todo aquellas que, como éstas (y nos referimos a las fotos de todos los museos de la subversión), son

37 "Compatriotas frágiles de memoria parecen olvidar hoy lo que ocurrió ayer en el suelo patrio", en: La Voz del Interior, 26/09/1980, p.5. 
fotos asediadas por la pérdida. O mejor dicho: por la presencia y la insistencia de aquello que se quiso borrar (FELD, 2014). Porque no nos olvidemos que estos museos fueron desmantelados, negados, lanzados al olvido. Queremos decir: fueron expresamente desbaratados. ${ }^{38}$

Toda foto es de algún modo una supervivencia. Registra, como señala Barthes (1989), el misterio de una concomitancia: testimonia que lo que veo, ha sido. Porque la fotografía -agregaría Castel (2003)- no es más que la representación de un objeto ausente como ausente. En estas fotos puntuales, sin embargo, la supervivencia adquiere otras resonancias. Atestigua algo que ya no es, pero eso a lo que refiere y sobrevive no es un espacio meramente perdido por obra del tiempo o del destino. Es un espacio desaparecido, y la elección del adjetivo es expresa. Por eso creemos que las fotos de los museos de la subversión vienen a llenar ciertos vacíos. A darle materialidad a eso que falta, a eso que quiso borrarse. Sabemos que el registro fotográfico documenta. Que el registro fotográfico prueba. Sontag (2006) decía que el registro de la cámara también incrimina.

Toda foto de estos museos es sobreviviente, pero las de Córdoba -las de Rafael Calviño- lo son aun de otro modo. Arrastran otra particularidad. Son, hasta ahora, las únicas imágenes originales que tenemos de ese Museo. ${ }^{39}$ Es decir, en su carácter de imágenes de una calidad a la que no accedemos a través del papel del diario. Y las tenemos justamente porque sobrevivieron a otra clase de vaivenes: sobrevivieron al destino de pérdida que tenían probablemente asegurado de haber quedado alojadas en un archivo editorial como el de Atlántida, hoy por hoy devastado y/o inaccesible. 40

\footnotetext{
${ }^{38}$ Poco sabemos, de hecho, sobre sus finales. Se dice que el de Campo de Mayo -quizás el mejor documentado- fue cerrado (más bien destruido) en 1981, a causa de la visita de un grupo de la Organización de los Estados Americanos (OEA) que venía a investigar los centros clandestinos de detención de la dictadura (SIRIMARCO, 2019b). Las fotos de los restos materiales de ese Museo, encontrados por el Equipo Argentino de Antropología Forense (EEAF) al excavar en 1998 en el centro de un chalet del predio, bien podrían ser una continuidad de las que acá presentamos ("La represión no se acabó con la democracia", diario Página/12, 15/03/1999, en: https://www.pagina12.com.ar/1999/99-03/99-03-15/pag08.htm). Consultado el 09/08/2021.

${ }^{39}$ Exceptuamos adrede las imágenes impresas de La Voz del Interior, cuyos originales no sabemos si han sido conservados en los archivos fotográficos del diario.

${ }^{40}$ Dice, sobre esos años y esa editorial, Tito Lo Penna: "Yo como fotógrafo, ingenuamente, sacaba fotos pensando que en algún momento se podían recuperar esos archivos (...) Era una ingenuidad pensar que quedaban en el archivo" ("El fotógrafo de Para Ti que retrató a la mujer secuestrada en la ESMA, Infojus Noticias, 02/12/2013, http://www.archivoinfojus.gob.ar/nacionales/elfotografo-de-para-ti-que-retrato-a-la-mujer-secuestrada-en-la-esma-2453.html, consultado el 13/08/2021). Sobre la misma línea advierte el por entonces fotógrafo de Noticias Argentinas (NA), Eduardo Longoni: "el negativo se quedaba en la agencia. A veces se quedaba en la casa de uno, digamos. Bueno, esa fue la manera como se salvaron muchas fotos, porque en las agencias hicieron
} 
La historia de esas fotos es, por eso, la historia de ese azar. Uno que comenzó el día en que Rafael decidió quedarse algunas de las fotos que había sacado en ese rollo:

Cuando vos ibas a hacer una nota, en el caso de que hubiera diapositivas, o blanco y negro, como era al comienzo (porque a partir de fines de los ‘70, el 90\% era color), vos lo mandabas a revelar, que estaba el laboratorio ahí mismo. Te daban el revelado, y vos lo que hacías era no una edición, sino que tenías la obligación de cortarlo, en tiritas de seis. Y lo que hacías habitualmente era sacar [las fotos que no servían], porque por ahí había [fotos de] otra nota [en el rollo], o unas fotos que habías tirado, de prueba, al piso. Lo limpiabas, y algunas veces te quedabas con alguna. Lo que pasa es que, si era una nota importante, también por una cuestión mía profesional, no te ibas a quedar con lo mejor. Porque vos decías: "bueno, si esto se va a publicar", vos le estás cortando justo [las fotos "buenas"]. En este caso yo tenía casi la seguridad de que eso no iba a ser publicado. Porque yo nunca había cubierto nada que tuviese que ver con el gobierno, ni nada de actualidad. Que me hubiesen mandado a mí, y encima sin cronista -porque además fui sin cronista-, era indicio que esa visita no era muy importante. Yo pienso ahora que ese viaje fue un poco marginal. Y para ese momento Videla ya se estaba yendo...

La nota se suponía que era para la revista "Gente", y hasta donde Rafael recuerda, nunca salió publicada. ${ }^{41}$ Se quedó con algunas pocas fotos; la práctica era usual entre quienes sabían que muchas fotos anteriores se habían perdido y sentían que eso podía volver a pasar. ${ }^{42} \mathrm{Y}$ las guardó en una "raviolera". Y

estropicios. Yo todavía hoy sigo lamentando no haber sacado más, no haber sacado todo, porque lo que estaba ahí se perdió" (DEL CASTILLO TRONCOSO, 2016, p.235).

${ }^{41}$ Como nos recuerda Diego Nemec, a comienzos de 1980 la Comisión Interamericana de Derechos Humanos (CIDH) hizo público el informe para la Argentina. La "respuesta" del gobierno dictatorial fue reforzar el discurso sobre la existencia de una guerra. Distintas medidas exhibicionistas -recreación de batallas, inauguración de pueblos, los museos mismos- bien pueden leerse bajo esta intencionalidad de relato (NEMEC, 2019). La irrupción de este informe, sumada a la deslegitimación y pérdida de capital político del gobierno para ese entonces, tal vez pueda explicar también -como bien apunta Rafael- que ciertos eventos fueran cubiertos por las editoriales, pero no finalmente publicados.

${ }^{42} \mathrm{Y}$ entre quienes sentían, sobre todo, que en ese presente en el que muy poco se podía hacer, preservar algunas fotos era una forma de hacer algo. Como recuerda también Horacio Mucc: "El fotógrafo volvía de una nota, cortaba un negativo y se lo llevaba a la casa, pensando 'esta la hice para mí porque sabía que no se podía publicar, se la guardaba sin saber qué hacer con ella pero sintiendo que esa foto había que protegerla" (GAMARNIK, 2013, p.178). O como dice Eduardo Longoni: "una de las cosas que hice, que fue tal vez una de las diferenciaciones con mis colegas de ese momento, es que me guardé el material, siempre fui superprolijo con guardarme las cosas. $\mathrm{O}$ guardaba una copia o guardaba un negativo que me interesaba. Y si había que revelar y fijar rápido, 
después se olvidó, hasta que Atlántida echó a varios de sus fotógrafos, justo "la gente más piola". Estaban, en ese grupo, Silvio Zuccheri, Rafael Wollman, Tito La Penna, Eduardo Bottaro, todos más o menos de su generación:

Y ellos hicieron una agencia, que se llamaba "ILA", "Imagen Latino Americana". Los habrán echado en el '80, '81. Tuvieron el pedo de que, justamente, este Rafael Wollman había ido a hacer una nota a Malvinas, que fue cuando fue la invasión, que son las únicas fotos [que hay]. Y con eso se movieron mucho. Entonces yo les había dado [las fotos que había guardado], porque habían hecho un contacto con una agencia internacional que se llama GAMMA. Entonces yo se las di, se las ofrecí. Les di las fotos esas y [ahí] quedaron. Suponete que se las habré dado a comienzos de los ' 80 y me las devolvieron, no sé, a fines de los ' 80 , comienzos de los ‘90. Mucho tiempo después.

Después de eso las fotos siguieron guardadas, inéditas. ${ }^{43} \mathrm{Y}$ después de algún tiempo más, las conocí. Su historia guarda un camino paradójico. Porque sabemos que la dictadura fue una usina de propaganda. Y que la fotografía de prensa fue una herramienta recurrente para el diseño y el sostenimiento de políticas oficiales. La editorial Atlántida, sin ir más lejos, fue un pilar importante, desde ya no el único, en las campañas de "acción psicológica" que justificaban, ocultaban o celebraban las prácticas del gobierno de facto. No sólo en palabras, sino también en imágenes: creando, en lo visto, la expectativa de realidad; invistiendo ese recorte gráfico de un halo de indiscutida autenticidad (GAMARNIK, 2012, 2015).

Así y todo, estas fotos, tomadas en actos oficiales, pagadas por medios de prensa cómplices de la dictadura (GAMARNIK, 2013), logran re-convertir lo panfletario en incomodidad. ${ }^{4}$ Lo hacen por el mero hecho de haber

porque había que meterla en el servicio rápido, yo después sacaba el rollo y lo fijaba de nuevo, lo lavaba, y si había una foto que me gustaba, me cortaba el negativo y lo guardaba" (DEL CASTILLO TRONCOSO, 2016, p.235).

${ }^{43}$ Aunque buscando en la web puede encontrarse una. Aparece-Rafael no sabe cómo- en un posteo sobre historia reciente. La imagen figura sin créditos y perdida entre otras. De ella se dice, erróneamente: "En la imagen 8, Videla recorre el denominado "Museo de la Subversión" en la ciudad de Córdoba durante el año 1979". En: http://www.proyectoallen.com.ar/3/?p=5413. Consultado el 15/08/2021.

${ }_{44}$ No nos referimos con esto a actos voluntarios de resistencia, como tomar (y guardar) fotos pasibles de ser censuradas, ni tomar (y publicar) fotos que ridiculizaran a personajes importantes de la dictadura. Nos referimos acá al simple hecho de que la foto de cobertura que sirviera, en su momento, como documento de propaganda, se volviera, con el tiempo, y una vez destruidos los espacios retratados, evidencia innegable de aquello que había querido borrarse. Volveremos sobre esto. Para una profundización en torno al primer eje, ver Gamarnik 2010, 2013. 
sobrevivido. Al paso del tiempo, como primera instancia, a la espera de otras condiciones de visibilidad. Pero también, en el caso particular de las fotos de estos museos, lo hacen por haber sobrevivido a los museos mismos. Por habilitar ese trozo de pasado en el presente; por sustraerlos de lo improbable (en su sentido de evidencia); por exponerlos -literal y figuradamente- al escrutinio de la historia (MENDIARA, 1999).

Si hemos desandado el recorrido de las fotos del museo de Córdoba fue justamente para llegar hasta acá: para inscribir esas fotos en un género específico -el de la fotografía de cobertura-, y para revelar, al hacerlo, no sólo una técnica, sino también una trama de posibilidad. No sólo un juego entre la cosa y su imagen, sino un juego entre el fotógrafo y su hacer. Y un juego entre dictadura y publicidad. Porque la fotografía de cobertura sigue ciertas características, y esas características nos hablan tanto de la foto como del evento, y al hacerlo nos hablan también del evento y su finalidad. Una foto decía Barthes (1989)- es siempre invisible: no es a ella a quien vemos. ¿Qué dejan ver, entonces, esas fotos de prensa? A través de ellas, pero también a pesar de sí mismas. ¿Qué dejan ver, esas fotos, sobre la relación entre museo y desaparición?

\section{Fotografía de cobertura. La exhibición pública}

Una cosa es la foto como documento, señala Didi-Huberman (2004), el resultado visible, la información. Otra, el testimonio que nos ofrece del propio fotógrafo: el riesgo, la urgencia, el enfoque. Es decir, la relación decisiva del fotógrafo con su entorno y con su técnica (BENJAMIN, 2013). La imagen fotográfica, como contingencia pura, no es algo que se pueda concebir fuera de sus circunstancias (DUBOIS, 1986).

Este apartado busca interrogar las fotos del museo de Córdoba desde ese otro lugar: no desde la cosa retratada, sino desde su producción. Busca no inducir el lenguaje a un esfuerzo de descripción que siempre resultará insuficiente (BARTHES, 1989): mirar las fotos y decir lo que en ellas se ve. No a causa de esnobismo, sino de estrategia, porque mirar las fotos desde la experiencia del fotógrafo, el oficio, nos permite restituir algo más que el objeto fotografiado. Nos permite prestar atención al modo -encuadres, focos, composiciones- en que el fotógrafo de prensa capta y transmite la imagen de lo que ha visto. Para poder interrogar, de ese modo, este género de fotografías que cubren -periodísticamente- un acontecimiento. 
Existe, dentro del género, una premisa que debemos acordar. Que aquello que registra la fotografía tuvo efectivamente lugar. Sabemos, por supuesto, que la cámara no es, necesariamente, un testigo objetivo. Sabemos que la fotografía no es sólo un proceso de registro mecánico, ni mucho menos la representación aséptica de lo "verdadero". Sabemos que existen las ediciones y los montajes. Sabemos que -hasta en el mundo del fotoperiodismo- hay escenificaciones. ${ }^{45}$ Pero nada de esto impide, sin embargo, que aceptemos dos puntos de partida, al trabajar sobre el corpus de fotos de este texto. El primero, del orden de lo volitivo: se espera que la credibilidad sea la base del periodismo de prensa. El segundo, del orden de lo fáctico: no creemos que pueda negarse que las fotos de Rafael Calviño constituyen un testimonio real. Eso que muestran, señalaría sintética y contundentemente Barthes, ha sido. El referente captado por la cámara -el museo- debió estar allí para que la imagen se produjese.

Pues ese es justamente el objetivo de la fotografía de cobertura: la representación fiel de un suceso; la aprehensión de un momento de la realidad. Y siempre con un fin informativo. Las imágenes de este género deben concentrar noticia y actualidad, pues su interés no se dirime por el manejo virtuoso de lo técnico o lo estético (son estos, en todo caso, valores agregados). Su importancia se salda con una operación más simple: la de dar cuenta de algo que está ahí (ULANOVSKY, 2009).

¿Cómo se logra? ¿Cómo se da cuenta, fotográficamente, de un acontecimiento? Se trata, en primer lugar, en este caso puntual, de seguir el evento. Es una obviedad, pero vale la pena resaltarlo. El seguimiento -la cobertura- no es un mero retratar sin dirección ni sentido, sino el intento de fijar, gráficamente, tres coordenadas básicas: el hecho (o el personaje), el contexto, la acción.

Es más, cuando saqué la foto no me di cuenta que estaba Bussi ahí. Yo estaba siguiendo a Videla. Por lo visto era como una visita a Córdoba, y fue ahí y a algún otro lado, supongo. Es más, [Bussi] no debe haber estado en ninguna otra circunstancia más que ahí. Que ofició de anfitrión, me parece. Por la actitud, digo.

Las fotos de Rafael son elocuentes. Se sigue a Videla. Se lo sigue en su circular por un recorrido. Se lo sigue centralmente. Lo suficientemente cerca

\footnotetext{
${ }^{45}$ Ver por ejemplo el caso de las fotos de migrantes de Dorothea Lange, o las fotos de la bandera de Iwo-Jima de Joe Rosenthal. O hasta las famosas fotos de Robert Capa sobre la muerte de un miliciano (MRAZ, 2003).
} 
como para volverlo el objeto de la foto, pero con el encuadre lo suficientemente abierto como para inscribirlo en un lugar. ${ }^{46}$ Esto es, para situarlo espacial y relacionalmente. Se estira apenas la perspectiva para dejar entrar algunos uniformes. En fila india, o cortados por el encuadre, otros militares lo siguen (Bussi incluido), a modo de comitiva. Videla es, en esas fotos, el acontecimiento. No Videla por sí mismo, sino el personaje en el contexto. No hay equívocos posibles. Las fotografías muestran -en el pacto fotográfico que corresponde al género- que Videla estuvo ahí. Que Videla visitó el Museo.

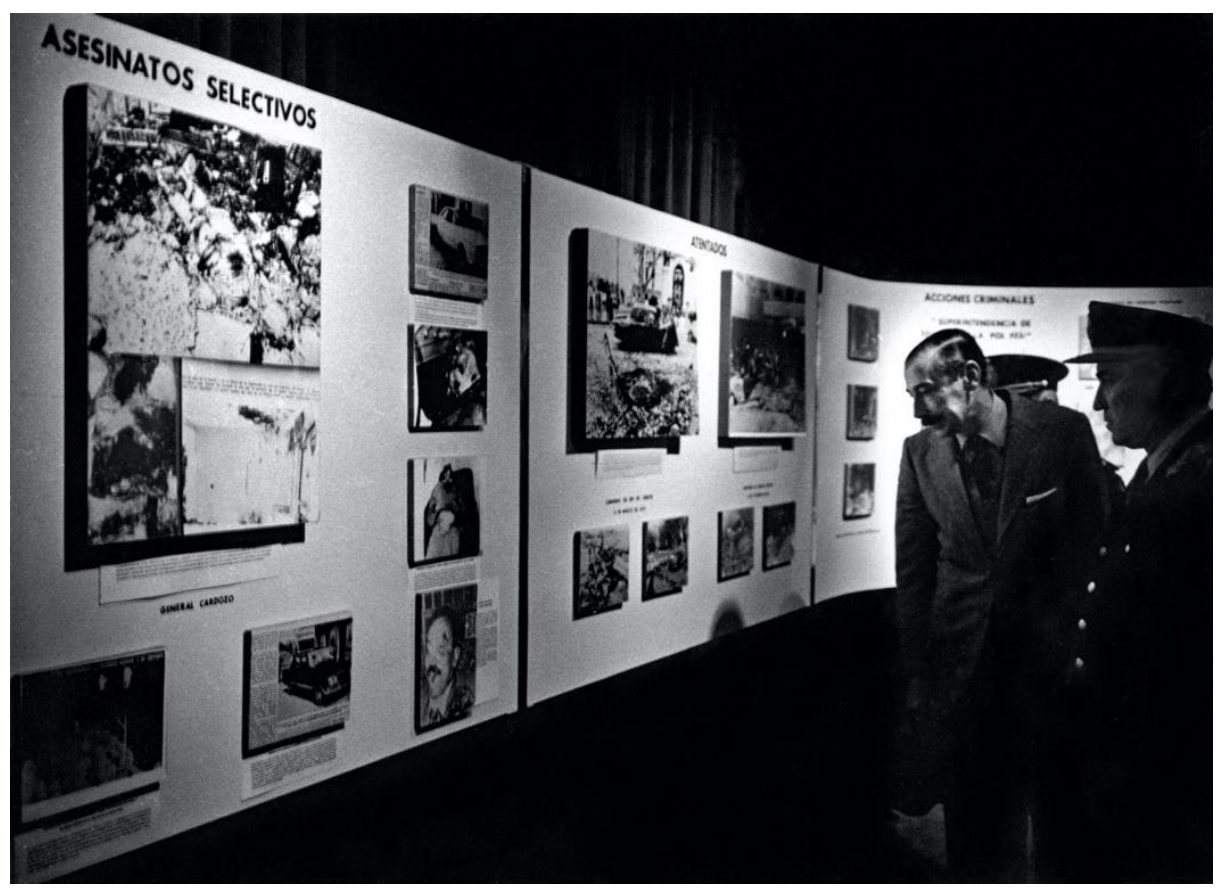

${ }^{46}$ En este sentido, las fotos de Rafael difieren mucho de las publicadas en la revista Gente con motivo de la inauguración del Museo de Campo de Mayo, en 1978. Son éstas, fotos de puros objetos en primer plano. Al propio Rafael le llamó la atención este encuadre cerrado: "me llamó la atención que no hay lo que nosotros llamamos una "vista". Es decir, un lugar donde se ve el ambiente del Museo. Son todas tac, tac, tac, tac [sonido de gatillar fotos]. No es el estilo de la revista. Digo, por ahí [el fotógrafo, Humberto Speranza] la sacó y se decidió editarlo así por lo fragmentario de los relatos. Pero lo habitual es que te mandan a hacer, no sé, [por ejemplo, fotos] en este bar, y te saco a vos, tomando café, y saco un detalle. Pero tratás de sacar algo que sea el frente, que se vea algo y que pueda servir a lo que llamamos, para una revista, la "apertura". Lo que muchas veces era una doble página". 
Personaje, contexto, acción. Se trata, además, de seguir a Videla en su hacer. Y lo que se hace, por antonomasia, en un Museo, es mirar. Mirar y recorrer. O más precisamente: recorrer mirando. Las fotos muestran a Videla en su deambular, lo inscriben en su paseo, apuntan a su interés. Y su interés está en la mirada. Está en lo que ve. Allí está para eso la comitiva: para mirar lo que Videla mira, para amplificar la atención hacia eso que vemos porque él lo mira, porque es el objeto de su observación. Se mira con él, pero también se le señala qué mirar: el índice de Bussi literaliza la clave que arroja Barthes sobre el acto fotográfico. Dice este autor que ninguna foto puede salirse del lenguaje deíctico. Que toda foto es la muestra de una contingencia; que toda foto lleva la marca de una referencia. Mire, ésta es mi casa. Vea, éste es mi hermano (1989). El dedo índice de Bussi parece decir lo mismo: vea, esto es un subversivo. La imagen dentro de la imagen, reforzando su deixis. Las fotos muestran a Videla mirando lo que le indican mirar, para que nosotros también, como la comitiva, miremos con él. ${ }^{47}$

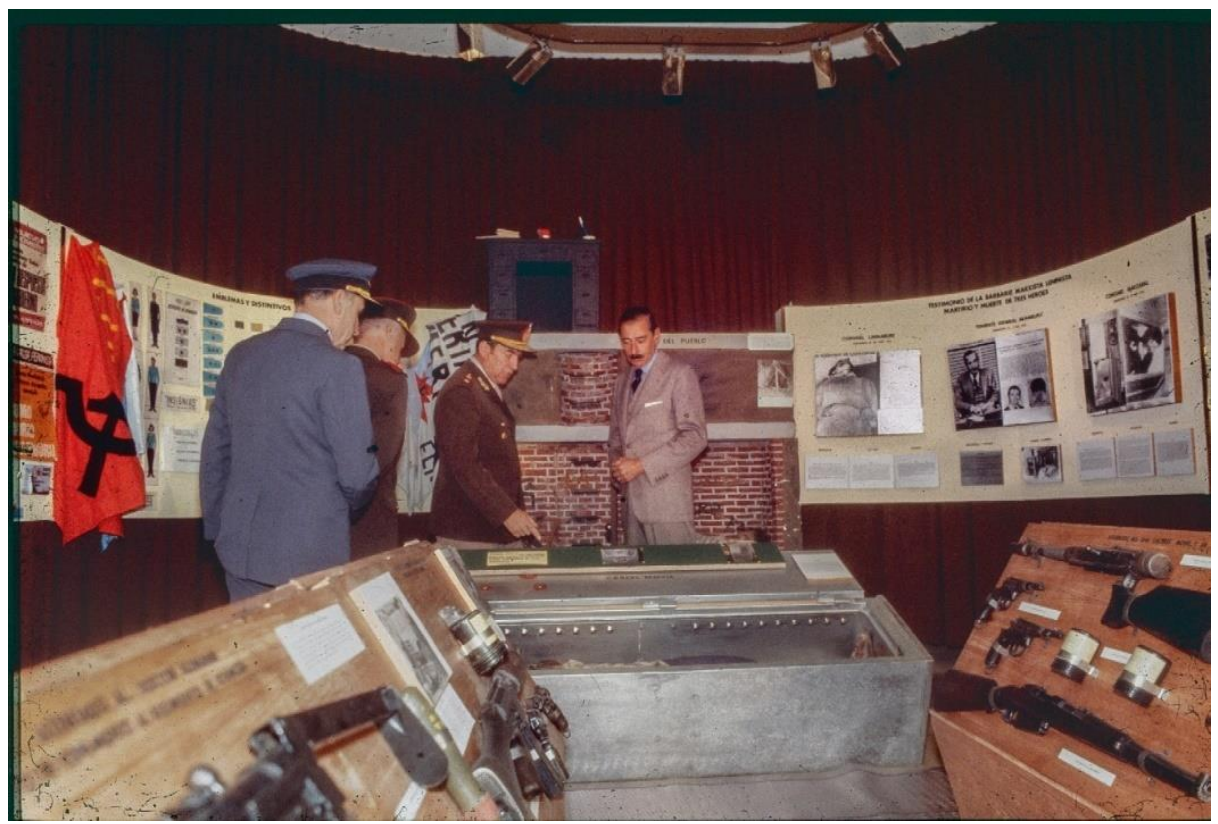

${ }^{47}$ Miramos hacia donde se nos señala mirar, pero eso no significa que no podamos mirar más allá. Nos ha resultado imposible no dejar de observar, en todas las fotos, el puño crispado de Videla. A la manera de un punctum, atrae nuestra mirada, se recorta de la escena como una flecha, nos punza, y al mismo tiempo tiene fuerza de expansión (BARTHES, 1989). 
¿Y qué miramos? La respuesta rápida es que miramos el Museo. La respuesta más sopesada es que miramos -como nos señala el dedo de Bussi- "la subversión". La profusión y la sumatoria de elementos ha creado un objeto. Lo ha explicado en paneles, lo ha mostrado en imágenes. Lo ha materializado en objetos, presentándolo y significándolo en un orden de lectura que nosotros, espectadores, sólo atisbamos: libros, fotos, armas, banderas, emblemas, cárceles, muñecos:

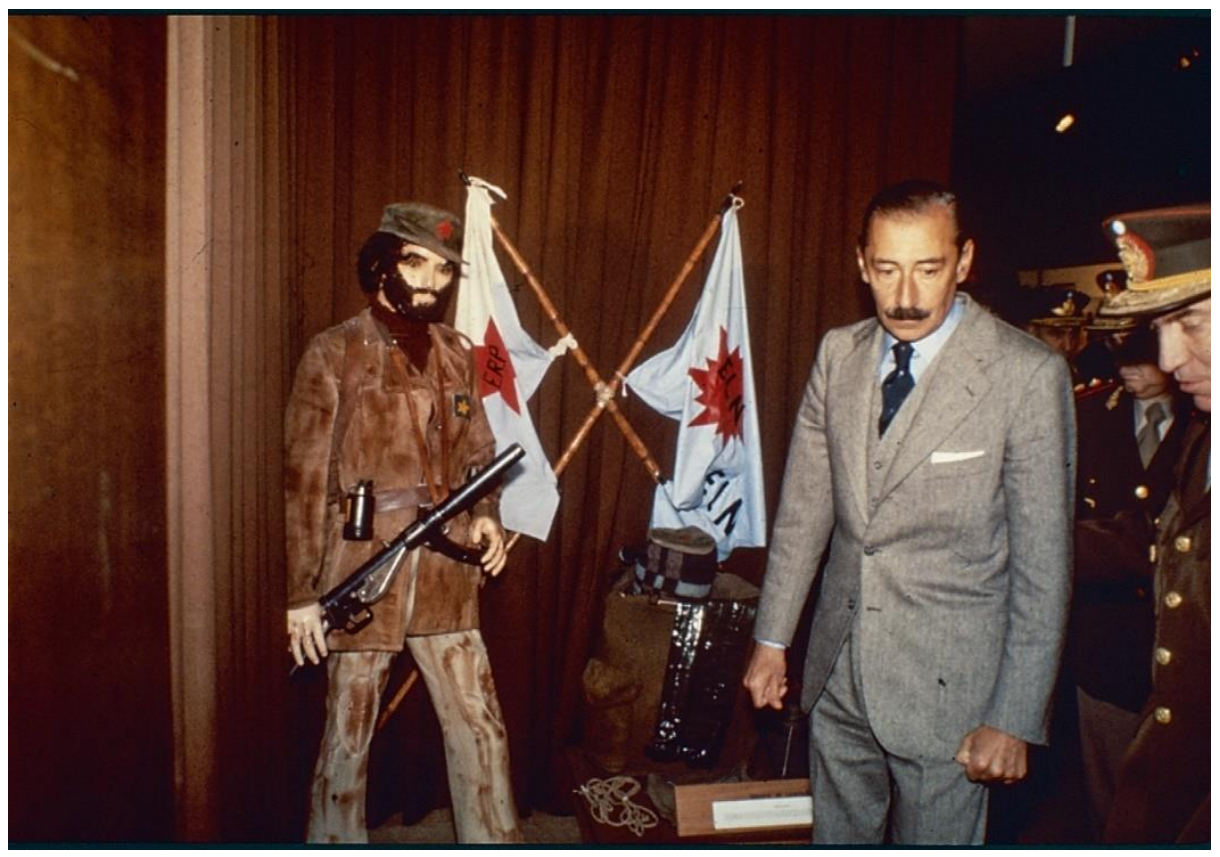

El salón estaba acondicionado dentro de una instalación. Era relativamente pequeño, el lugar. No minúsculo, pero pequeño. Tenía ese aire medio trucho, de puesta casi que escolar. De haber colgado unas cartulinas. Ahí estaba un poquito más emprolijado, pero era una versión no demasiado sofisticada. Estaba el maniquí ese ridículo. Ese Museo me da la sensación de que era una kermese. Me acuerdo que yo me apuré a sacar la foto junto a ese muñeco, cuando [Videla] se iba. Es parte del oficio: sabía que iba a pasar por ahí y entonces me apuré para mostrarlo con el muñeco ese. Para sacar una foto más ágil, que muestre algo. 
Para sacar una foto que muestre, podríamos añadir, el epítome de "la subversión" como asunto. Que muestre -mediante el guerrillero ya vuelto objeto (maniquí)- el movimiento último de la cosificación.

Pero el método de la fotografía de cobertura no se agota en lo que vemos retratado, en aquello que aparece dentro del encuadre. También sus excedentes -lo que queda fuera del campo- forman parte del modo en que se ejerce la práctica del género (SCHUFFER MENDOZA, 2019). Porque la captura del acontecimiento (quién, dónde, qué) viene indisociablemente ligada al cómo de esa captura. Y este cuarto elemento -el cómo- se vuelve otra de las características fundamentales de esta clase de fotografía. No hablamos acá de la técnica en sí misma, en términos de un desarrollo abstracto y auto-contenido. Hablamos de la técnica como vínculo: del diálogo que se establece entre ella y el contexto. O mejor dicho: hablamos de lo que las particularidades del entorno obligan en el acto de fotografiar:

El lugar era relativamente chico. Yo creo que había, apenas entrabas, ¿viste la foto esa, que se ve con el maniquí? Bueno, esa es como la salida, como un hallcito chiquito. Me parece. Que estaba como saliendo. Y después estaba una sala, que era donde estaba la foto blanco y negro, que estaba mirando. Y supongo que esa otra, que la tenía borrada, me parece que era una sala más grande, y era en un costado, donde viste que se ve que hay unas armas, unas vitrinas. Eso la verdad que no me acuerdo nada... Pero me acuerdo que me había impresionando estar ahí, frente a esos tipos, con todo lo que se sabía, más ya en esos años. En esos momentos uno apela a la profesionalidad. Y eso es lo que me quedó más fijado, porque claro, las fotos esas las saqué con la cámara con la que trabajaba, con flash, en diapositiva, digamos. Y la otra foto blanco y negro la saqué con una que tenía, una camarita chiquita, que la tengo que buscar, porque la había guardado de recuerdo, que era muy rudimentaria, digamos. Tenías que poner todo manual ... Hice la prueba y saqué una fotito chiquita, así. Y esa foto tiene un poco más de clima, aunque no está lo del maniquí, que no la podría haber hecho en blanco y negro porque me salía movido, no daba la luz. Estaba oscuro, viste que se nota. Había solo la luz que iluminaban los paneles.

Resulta interesante reparar en lo que Rafael está diciendo: no se acuerda mucho de nada -ni cómo era precisamente el lugar dónde estaba, ni qué era concretamente lo que allí había, ni si era el único fotógrafo; no se acuerda ni siquiera cómo había llegado hasta ahí. Sin embargo, sí se acuerda de las cámaras con las que trabajaba, de sus manipulaciones, de la luz que había, de dónde venía, y de lo que esa luz, en términos técnicos, le permitía o le negaba. 
Todo lo que era territorio y espacio recorrido forma parte, para él, de una impresión vaga. Lo que permanece firme, en cambio, es la impresión que le llega a través del visor de su cámara. Lo que nos dice Rafael apunta justamente a lo que intentamos subrayar: que su recuerdo del museo no está atado al lugar en sí, sino a su experiencia como fotógrafo en ese lugar. O lo que es lo mismo: que no recuerda nada que no estuviera mediado por la práctica de su oficio.

Un oficio donde, nos confirman las siguientes palabras, el cuerpo se vuelve herramienta primordial:

[Si había otros corresponsales], ahí, la verdad [no sabría decirte]... Otro fotógrafo, casi 99\% que no. ¿Por qué lo digo, eso? Por una cuestión, digamos, física. Que te das cuenta, porque siempre te entorpecés con el que está al lado. Hay fotógrafos que no, pero yo saco con todo el cuerpo, digamos. El físico está. Para los que trabajamos en la calle siempre hay una cosa que tiene que ver con lo corporal, ¿no? Así que casi seguro que no. Pero por ahí había uno, más institucional, que sacaba desde otro lado, y yo no lo recuerdo.

Y era justamente aquí a donde queríamos llegar. A cómo el oficio fotográfico no empieza ni termina en un ojo que replica realidad. A cómo el oficio fotográfico implica, siempre y necesariamente, el posicionamiento de un cuerpo en escena. No sólo para percibir lo que nos rodea -la existencia o no de otro fotógrafo, por ejemplo-, sino para generar una imagen determinada a la hora de presionar el obturador. Porque el cómo de la captura de una foto transcurre por fuera de sus márgenes, pero eso no significa que sea invisible. Queremos decir: que sea invisible dentro de la foto misma. La foto que vemos contiene ambas informaciones: la del acontecimiento en sí y la de dónde y cómo estaba (puso) el cuerpo el fotógrafo para retratarlo. La disposición de ese cuerpo en esa escena determina que veamos lo que vemos.

Se entenderá mejor lo que intentamos decir si recurrimos a algunos contrapuntos. Tomemos concretamente dos ejemplos. El primero, el de las fotos arrebatadas a la ESMA por Víctor Basterra a partir de 1980. La historia es ampliamente conocida: este detenido-sobreviviente encuentra en una bolsa negativos a ser destruidos. Los saca del lugar en sucesivas salidas, ocultándolos entre sus ropas. Salvo la veintena que él salva, el resto de los retratos -tomados de manera sistemática por los represores- va a ser destruido al finalizar la dictadura. Las imágenes son de detenidos-desaparecidos fotografiados de frente y de perfil. Vemos ahí las condiciones de cautiverio y de tormento. Las manos esposadas o atadas a la espalda. Los cordones de los zapatos desatados. 
Los rostros abotargados o desencajados. Las miradas perdidas. Las posturas encorvadas. En una palabra: vemos la desprotección, la vulnerabilidad, la sordidez (FELD, 2014; LARRALDE ARMAS, 2015).

El segundo contrapunto, el de las cuatro fotos arrebatadas a Auschwitz en agosto de 1944. El caso lo analiza Didi-Huberman, en un conocido texto (2004): un trabajador civil consigue introducir una cámara fotográfica al campo y hacerla llegar a los miembros del Sonderkommando. Escondida en el fondo de un cubo, la cámara llega a manos de un judío griego que trabaja en las fosas de incineración. Para sacar las fotos, el fotógrafo tiene que esconderse en la cámara de gas, apenas momentos después de retirados los cuerpos. Al resguardo de ese lugar ya vacío, consigue dos imágenes borrosas, enmarcadas por el sitio donde se encuentra oculto: se dejan adivinar, a lo lejos, los miembros del Sonderkommando junto a una pila cadáveres; en el fondo, se distingue el humo de las fosas de incineración. El fotógrafo sale del crematorio, bordea el muro, camina hacia el bosque. Un convoy de mujeres, ya desvestidas, marcha hacia la cámara de gas. Con las SS alrededor, el fotógrafo no puede sacar la cámara con total libertad. Mucho menos, enfocar. Logra otras dos imágenes, a toda prisa, tal vez sin mirar, quizás mientras sigue caminando. Son completamente borrosas. Poco más que manchas de luz y oscuridad. En una reconocemos la presencia de un Sonderkommando por el perfil de la gorra. La otra es todavía mas evanescente: apenas distinguimos la cima de unos abedules. El fotógrafo vuelve al crematorio, devuelve la cámara al trabajador, la película logra salir de Auschwitz escondida en un tubo de pasta dental.

Hay dos cuestiones que quisiéramos subrayar en estos ejemplos. El primero nos pone frente a la mirada de los perpetradores: en esas fotos no sólo vemos a las víctimas; las vemos además desde la perspectiva del secuestrador (Larralde Armas, 2015). Son fotografías sacadas desde el adentro. El segundo ejemplo nos enfrenta, en cambio, a fotografías sacadas desde el afuera. Son fotos desde el movimiento, desde el desconcierto, desde la circunstancia. La dificultad del encuadre, lo borroso y lo "movido" son, en ellas, una marca visual: la huella del obstáculo y del peligro corrido (BOLTANSKI, 2003; DIDI-HUBERMAN, 2004). El afuera y el adentro, entonces, como primera cuestión.

Y una segunda: comparten ambos ejemplos una característica, que hemos intentado señalar lexicalmente al presentarlos. Se trata, en la ESMA y en Auschwitz, de fotos arrebatadas. Por quien las salva, en el primer caso. Por quien las toma y exfiltra, en el segundo. El arrebato no indica acá, en este segundo caso, el quién del acto de la fotografía, sino el cómo del posicionamiento frente a la desaparición y la violencia. En uno y otro caso, las fotos son arrebatadas 
porque su revelación -por fuera de su área de consumo, por fuera de sus murosexpone el espacio de lo clandestino. El arrebato se expresa aquí como la urgencia de un reflejo que permite sacar a la luz aquellos actos perpetrados para una novisibilidad. Estas "capturas" -término que adquiere así una siniestra pertinencia- encuentra en el arrebato las condiciones de su visibilidad futura.

Volvamos ahora a las fotos del museo de Córdoba. No hay, en ellas, ni adentro ni arrebato. Tampoco hay un afuera que imponga ángulos vertiginosos, ni encuadres en velocidad, ni desenfoques. Y todo eso que no hay, también es una marca. Una que habla del fotógrafo en acto y que aparece en la información que nos devuelve la imagen. Porque lo que hay en esas fotos es el resultado del tiempo acordado a la toma, la convención y el consentimiento. Videla, Bussi y la comitiva recorren los pasillos del museo, se exponen al objetivo, con la conciencia de convertirse en imagen. Esas presencias encarnan pose y protocolo, un control de la presentación personal que desborda lo individual para representar un evento institucional.

Aquí el fotógrafo tiene a disposición un repertorio bien determinado de decisiones técnicas: encuadre, foco, composición. Hay personajes vistos con nitidez, objetos discernibles, porque el fotógrafo dispone de tiempo para capturar el evento. Más allá de las limitaciones luminosas o espaciales que impusiera el espacio, hay composición en el manejo de la perspectiva. $\mathrm{Ni}$ manchas borrosas ni granulados. No se trata de un cuerpo urgido por el riesgo o el disimulo, porque tiene autorización para fotografiar. Para decirlo de una vez: hay un fotógrafo que acompaña una comitiva oficial y que trabaja al abierto.

Si en estas imágenes de Rafael Calviño no hay nada que exponga su cuerpo -que enfrente la práctica de su oficio- a las condiciones del arrebato de la imagen que venimos argumentando, se nos dirá que no hay nada que vincule estas fotos con la desaparición o lo clandestino. Eso es justamente lo que nos interesa discutir a continuación: la relación de estas fotografías con la violencia. O para ser más precisas: la relación de estas fotografías con una suerte de violencia desconectada. Con una que se exhibe voluntaria y abiertamente ante los fotógrafos de prensa, por considerarla incapaz de reflejar nada.

\section{Museos y desaparición, la cara invisible (A modo de conclusión)}

Seguir los últimos tramos del argumento de este texto exige la reposición de ciertos datos. Aquellos que permiten, justamente, devolver la conexión rota: unir a los museos de la subversión con las múltiples formas de la violencia. Esta 
reposición entraña un recordatorio y un nuevo apunte. El recordatorio es a la vez hipótesis de trabajo ya presentada: que fue Bussi quien organizó y dio forma institucional ${ }^{48}$ a estos museos. $\mathrm{Y}$ con esto no estamos solamente mencionando un nombre, sino resaltando un carácter. Bussi fue uno de los militares más públicamente implicados en la represión ilegal estatal, con causas abiertas en su contra -en el país y en el extranjero- por violaciones a los derechos humanos, y finalmente condenado en 2008 por delitos de lesa humanidad en la provincia de Tucumán.

Déjennos sumarle ahora otros matices al listado de cargos y destinos con que abríamos este texto. Bussi fue jefe de la Subzona 32, cuya jurisdicción abarcaba la provincia de Tucumán, desde entre 1975 y 1977, e interventor de dicha provincia de 1976 hasta 1977; ambas posiciones lo transformaron en el responsable de todos los centros clandestinos de detención que funcionaron en la zona, como así también del control operativo de las Fuerzas Armadas y de Seguridad. Fue luego, entre 1977 y 1979, el segundo comandante de Institutos Militares y el jefe del Estado Mayor del Comando de Institutos Militares, radicados en Campo de Mayo; en el ejercicio de tales cargos tuvo jurisdicción en los partidos bonaerenses de Escobar, General Sarmiento, General San Martín, Pilar, San Fernando, Tigre, Tres de Febrero y Vicente López. Fue comandante del III Cuerpo de Ejército durante 1980 y, como tal, jefe de la Zona 3, que abarcaba las provincias de Córdoba, Mendoza, Catamarca, San Luis, San Juan, Salta, La Rioja, Jujuy, Tucumán y Santiago del Estero. Fue, finalmente, comandante del I Cuerpo de Ejército hasta 1981, cuya jurisdicción comprendía la Capital Federal y la provincia de Buenos Aires (con la excepción de algunos partidos del sur). ${ }^{49}$ Por supuesto, no hablamos acá de cargos en términos nominales. Nos referimos, en cambio, a lo que el desempeño de ese cargo abarcaba. En la larga declaración de sobrevivientes y testigos, se ha señalado reiteradamente que era Bussi mismo quien comandaba las sesiones de tortura y quien, para dar el ejemplo, daba el primer tiro de gracia en los fusilamientos masivos (MARCOS, 2005).

A la luz de este recordatorio, entonces, el nuevo apunte. Uno que viene a presentar algunos datos que son, al mismo tiempo, el corolario sospechable de esta enumeración de cargos y destinos. Nos referimos, concretamente, a la estrecha ligazón que existe entre museos de la subversión y detención ilegal.

\footnotetext{
${ }^{48}$ Conviene no olvidar, como se verá más adelante, que la exhibición de materiales secuestrados en la actuación del oficio es una práctica generalizada, que bien puede entenderse como paralela o preexistente a la figura del museo formalizado.
}

${ }^{49}$ Ver: http://www.derechos.org/nizkor/arg/doc/bussi1.html. Consultado el 12/08/2021. 
Otra vez, los datos son contundentes: el Museo de la Policía funcionó en la jefatura policial en San Miguel de Tucumán, allí donde funcionaba uno de los centros clandestinos más importantes de la provincia. El Museo Histórico "Mayor Don Juan Carlos Leonetti" funcionó en la base militar de Campo de Mayo, en cuyo emplazamiento funcionaba el mayor campo de detención clandestino dependiente del Ejército. El Museo de la Lucha contra la Subversión funcionó en el Comando del III Cuerpo de Ejército, gigantesco predio -correspondiente a la estancia La Perla- donde funcionaba uno de los centros clandestinos más grande del interior del país. ${ }^{50}$

La conclusión es tan evidente como perturbadora. Las colecciones de estos museos no sólo desplegaban un discurso triunfalista de lucha contra la subversión, sino que lo hacían en los escenarios mismos donde esa lucha daba sus puntadas finales. El museo de la subversión a pasos nomás del centro clandestino. Compartiendo la misma geografía, en una prestidigitación de luces y sombras, que operaba sustrayendo algo de la vista y poniendo en foco, adrede, otra cosa. De un lado lo abiertamente visible, el museo. Del otro, lo clandestino (la detención ilegal, la desaparición, la tortura). Fluyendo entre ambos, el espanto de lo real. El contrapunto era implacable. En un juego perverso entre la literalidad y la tapadera, la retórica de la lucha contra la subversión encubría al terrorismo de estado, la exhibición de "trofeos" ocultaba a los detenidos. El delante y el detrás, teatro y espanto (SIRIMARCO, 2019b). Y en las fotos del museo de Córdoba, esas pesadas cortinas de un color indefinido tirando al rosa viejo.

Este movimiento de acoplamiento ya ha sido reseñado. Jean y John Comaroff resaltan esta dualidad, por ejemplo, para el museo policial de Sudáfrica en 1999: "el espacio de la exhibición pública había coexistido, en tiempos del apartheid, con algo más, con algo clandestino, con algo actualmente aborrecible: el epicentro -y el espacio de interrogación- del tristemente famoso servicio de seguridad nacional. La bizarra coexistencia de ambos dentro de las mismas paredes -el museo abajo, la policía secreta arribaparecía rebasar cualquier coincidencia" (2004, p.810). Lo mismo puede decirse de estos museos: detenidos de un lado, objetos museísticos del otro. El anverso

\footnotetext{
${ }^{50}$ Dejamos fuera de este listado al probable Museo en el Regimiento I de Patricios, del que aun no tenemos datos concretos. Se sabe, sin embargo, que dicho Regimiento funcionó como centro clandestino durante la dictadura. Ver, por ejemplo, el listado elaborado por la Secretaría de Derechos Humanos de la Nación:

http://www.jus.gob.ar/media/3122963/6._anexo_v__listado_de_ccd.pdf. Consultado el $08 / 08 / 2021$.
} 
y el reverso "del estado como violencia. No había una simple línea divisoria, en este edificio con dos entradas, entre las bambalinas y el frente del escenario, entre actores y audiencia, entre los productores y los consumidores de una realidad fantasmagórica" (COMAROFF, 2004, p.816).

Pero no debe creerse que esta dualidad implicara un simple movimiento de proximidad. Implicaba, sobre todo, un movimiento de prolongación. Porque estos espacios -centros clandestinos y museos- no sólo compartían la misma geografía. Compartían, además, los mismos insumos. Reparemos, si no, en la naturaleza de lo expuesto: armas, banderas, libros, ropas. ¿De dónde salían estos objetos? La respuesta es tan explícita como el espacio que los alojaba, y aparece una y otra vez -se recordarán las notas de La Voz del Interior- en letra de molde: "elementos todos ... secuestrados a las bandas subversivas en diversos procedimientos realizados por las fuerzas de seguridad". 51

Revisemos un ejemplo. En 1977, a un conscripto que hacía el servicio militar en el Regimiento de Infantería Aerotransportada de Córdoba (en el mismo enorme predio correspondiente a la estancia La Perla) lo llevaron a hacer una recorrida por el lugar:

Y en esa recorrida nos llevan a ese museo. Era una sala con mesas. Había ropa, documentos. Había objetos personales, desde lapiceras, relojes, zapatos, zapatillas ... "Acá están las cosas que nosotros recuperamos en cada uno de los combates que nosotros hacemos contra la guerrilla y la subversión", me acuerdo que nos dijo el milico que nos hizo la recorrida. "Estos son elementos de los subversivos". El "trofeo de guerra", así lo presentaban. Y estaba todo acomodado y organizado, no era una montonera de cosas. Y vos ibas recorriendo: veías los documentos de identidad... Obviamente, el argumento de los tipos era: "esto es lo que nosotros recuperamos y que ellos usaban identidades falsas". Eran documentos que los habían robado o fraguado, decían ... Después venían todas las armas. En general estaban como desarmadas; el cargador afuera y demás. Bien exhibidas, como en un museo. Después, literatura, obviamente. Panfletos. Fotos de lugares que habían allanado y habían copado. Cárceles del pueblo, por ejemplo. Pero no puestas en las paredes sino en las mesas ... Vos ibas parando en la mesa, "acá esta ropa, la ropa que recuperamos de los guerrilleros", te decía. Después pasabas a las armas: "estas armas, acá hay una 45 , acá hay esto, estas armas eran las que les quitaban a los policías y a los militares, matando". Yo recuerdo mucho el tema de la ropa. Pantalones, vestidos... Era ropa civil, no tengo el recuerdo de que fuera otra ropa, de fajina o militar. Hoy pienso que esa

${ }^{51}$ Las cursivas aquí son nuestras. 
ropa y esos documentos podrían haber sido de desaparecidos. Vos pensá una cosa. Lo que yo te estoy contando, el Regimiento de Infantería Aerotransportada 2 de Córdoba se toca con La Perla, con lo cual... Mirá, a nosotros a veces nos sacaban y nos llevaban a hacer unas especies de inspecciones que los milicos hacían, que cerraban un barrio entero, veinte manzanas, y nos llevaban a nosotros y nos ponían en cada punta y no entraba ni salía nadie. Y cuando volvíamos, siempre decían: "detuvieron a 10 guerrilleros". Nosotros no veíamos [nada], pero yo estoy seguro de que en ese regimiento donde yo estuve, o en el del frente, o en el del costado, los llevaban. Después los trasladarían a La Perla o a algún otro centro de detención (SIRIMARCO, 2020: s/d).

Reparemos en las palabras con que el militar que hace la recorrida explica el origen de los objetos: se trata-lo dice expresamente- de elementos "recuperados en combate". Combate, procedimientos, enfrentamientos. No hace falta explicar acá lo que esconden estos eufemismos. Lo que hay detrás de esas categorías. Tanto en sentido figurado como literal. Sabemos que detrás del combate está la desaparición. Y que detrás del museo está el centro clandestino (o el centro de captura, recepción y detención de subversivos). Y entonces, no es arriesgado pensar que detrás de la ropa "recuperada de los guerrilleros" esté, lisa y llanamente, la ropa que les fue sacada a los secuestrados.

Y acá es donde opera el truco. Porque museo y centro clandestino bien pueden concebirse como el delante y detrás de una misma escena (se trata, finalmente, de espacios formalmente distintos). Pero no hay delante y detrás posible en las ropas. Los zapatos que se exhiben de un lado, faltan del otro. No se trata de zapatos distintos, sino del mismo zapato. Se trata -y acá queríamos llegar- de la continuidad del mismo objeto (SIRIMARCO, 2020). Continuidad que sólo la traslación de un lado al otro (el simple pasaje del reverso al frente), hace aparecer como desconexión, ocultando que aquello que se muestra como objeto museístico, visible y legitimado, es también un objeto arrebatado zapatos, documentos, banderas, libros. ${ }^{52}$ Ocultando que se trata de un objeto impregnado por la violencia y lo clandestino. Ocultando, en suma, que ese objeto no atraviesa lugares inconexos, sino que habita lógicas que se presentan como aisladas pero que conforman en realidad un mismo espacio, sólo que con

\footnotetext{
52 Arrebato, violencia, objeto, exposición. Tal vez no se aventurado recordar acá que fue también Bussi quien, durante su gobernación de facto de la provincia de Tucumán, removió 144 menhires de su emplazamiento original en Tafí del Valle y los trasladó creando, en otra zona, un parque arqueológico. Tal vez no sea aventurado ver, en este caso, otro ejemplo de un poder que sustrae y repone, organizando y re-organizando la dirección de la mirada.
} 
dos entradas y una ausente línea divisoria entre las bambalinas y el frente del escenario (COMAROFF, 2004).

No hay, en los museos de la subversión, nada que se escamotee a la vista. Por el contrario: la visibilidad es total. Y sin embargo, ningún objeto de los que se exhiben -de los que se ostentan- proclama al abierto su conexión con la desaparición. Ni la proclama ni logra traslucirla. Y sorprende, en este movimiento de exposición, lo que a primera vista podría verse como audacia o desparpajo. El hecho de ofrecer a la vista pública -el museo, la fotografía de prensa- aquello que podría resultar incriminador. Y que pronto lo serían incriminadores- pues recordemos que estos museos fueron al final de la dictadura negados y expresamente destruidos. ¿Cómo era que estos objetos se exponían, en su sentido documental, como el testimonio de una lucha, sin lograr que expusieran, en su sentido culpabilizador, aquello que bajo esa retórica trataban de ocultar?

La respuesta es simple, e implica prestarle atención a la operación de embozo que requería la exhibición abierta de la represión clandestina en estas salas y museos. Señala Rufer (2018) que una forma de enmascarar la violencia es operar des/re/conectándola. Es decir, operar no enmascarando el objeto sino enmascarando su conexión con determinadas aristas de la experiencia. ${ }^{53}$ Ahí están, por ejemplo, los documentos de identidad en las mesas de esa sala del cuartel cordobés. No suprimidos, ni ocultados, sino reconvertidos: evidencia no de un probable detenido-desaparecido, sino prueba de cómo el guerrillero fraguaba identidades falsas. O sea: la violencia que porta el objeto, sanitizada y cambiada de signo (SIRIMARCO, 2019a, 2020; DAICH y SIRIMARCO, 2020). Y como tal -como sanitizada y legitimada-, ostensiblemente expuesta. Expuesta a la vista de los visitantes de estos museos. Expuesta a la lente de la fotografía de cobertura, que reificaba relatos y amplificaba espectadores.

La operación -lo vimos- era una constante en los medios de prensa. Nos referimos al ocultamiento y la sustitución. La aplicación del terrorismo de Estado necesitó de ambos movimientos: de una política de censura y de una política de reemplazo. Y necesitó de ambos movimientos en simultáneo: las luces y las sombras, el anverso y el reverso. De un lado la lucha, la subversión, el museo. Del otro, la represión, el desaparecido, el centro clandestino. Lo escondido debía encontrar una contraparte en la visibilidad, como figuras que

${ }^{53}$ Por supuesto, la supresión y/o reconversión de la violencia estatal no es inusual en los museos de las fuerzas armadas y de seguridad. Para un mayor desarrollo sobre este punto, ver Sirimarco 2019a. 
se suponen mutuamente, como elementos de un mismo fenómeno que no pueden verse a la vez (GAMARNIK, 2010; SCHINDEL, 2016).

De un lado la lucha, la subversión, el museo. Del otro, la represión, el desaparecido, el centro clandestino. $\mathrm{Y}$ en el medio, las fotos de prensa. Queremos decir: la fotografía de cobertura, a caballo entre lo exhibido y lo invisible. Materializando ella misma el juego entre lo que se ostenta y lo que se oculta; revelando, mediante la exposición de lo legítimo, aquello que se enmascara. En una palabra: dando testimonio gráfico de todo lo que cabe en lo expuesto, de todo lo que viene a semantizar ese exceso de visibilidad. Si existe, en todo orden, un dejo que no "cierra", un elemento que desestabiliza el relato, que se queda ahí como resto, que insiste, que nos asedia y que persevera, que vuelve todo el tiempo -diría Rinesi (2019)- como una sombra o una promesa, la fotografía de cobertura -estas fotos sobrevivientes- vienen justamente a recordarnos, merced a su supervivencia, que no toda violencia es sanitizable (SIRMARCO, 2020). Vienen a exponer el truco, a revelar las costuras; nos muestran todo lo clandestino que se cuela en el abierto.

Porque esas fotos no sólo operan como prueba de la existencia de estos museos, reponiendo, con su aspecto fantasmático, ese referente que fue perdido. Operan sobre todo como marca visual del nexo de violencia que fue roto. La razón es simple: los objetos -zapatos, banderas, museos- no son nunca una cosa inerte, sino una suerte de fósil en el cual está petrificada una constelación de fuerzas (BENJAMIN, en GORDILLO, 2014). Los objetos son cosas que hablan por sí mismas, aun desde ese sustrato de materialidad que se presume muda. El objeto habla, aun cuando se lo fuerce al silencio. Así como hablan las historias que no se quieren mostrar, y sin embargo se muestran. La violencia estatal deja marcas. Hasta en los lugares más insospechados. (DAICH y SIRIMARCO, 2019).

¿Cómo, las fotografías de estos museos, pueden considerarse fotos que aluden, claro que desplazadamente, a la desaparición? Que aluden al secuestro, a la detención ilegal, al asesinato, a su borramiento. Confíamos en que la pregunta que ha abierto este texto obtenga ahora su respuesta. Una sin dudas compleja y con múltiples capas de sentido. Una que permita inscribir estos espacios museísticos como dispositivos importantes en la maquinaria de la desaparición (en la maquinaria de su ocultamiento y de su reemplazo). Una que permita inscribir también en ella la fotografía de cobertura, en tanto imagen que expone lo abierto pero revela lo invisible, y que permita entonces reflexionar sobre cómo proceder para acercarse a esos registros invisibilizados. Una respuesta que nos permita, finalmente, reformular la pregunta del comienzo: 
¿cómo mirar aquello que permaneció des-conectado de su régimen originario de violencia?

\section{Agradecimientos}

Sin la ayuda de Mariana Tello, Ezequiel Torres y Diego Nemec, este texto no hubiera encontrado el rumbo. No hubiera sido ni siquiera posible sin el oficio y la generosidad de Rafael Calviño, que hace décadas guardó unas fotos y después nos las mostró.

\section{Bibliografía citada}

ALBERTI, Samuel

(2005). Objects and the museum. History of Science Society, vol.96, n.4, p.559-571.

ALMIRÓN, Fernando.

(1999). Campo Santo. Los asesinatos del Ejército en Campo de Mayo. Testimonios del ex sargento Víctor Ibañez. Buenos Aires, Editorial 21.

APPADURAI, Arjun.

(1991). Introducción: las mercancías y la política del valor. In: Arjun Appadurai (Ed.); La vida social de las cosas. Perspectiva cultural de las mercancías. México, Grijalbo, p.17-87.

BARTHES, Roland.

(1989). La cámara lúcida. Notas sobre la fotografía. Barcelona, Editorial Paidós.

BENJAMIN, Walter.

(2013). Sobre la fotografía. Valencia, Pre-textos, Valencia.

BOLTANSKI, LUC.

(2003). La retórica de la figura. In: Pierre Bourdieu (Ed.); Un arte medio. Un ensayo sobre los usos sociales de la fotografía. Barcelona, Editorial Gustavo Gili, p.207-234.

CASTEL, Robert.

(2003). Imágenes y fantasmas. In: Pierre Bourdieu (Ed.); Un arte medio. Un ensayo sobre los usos sociales de la fotografía. Barcelona, Editorial Gustavo Gili, p.330-377.
DAICH, Deborah y SIRIMARC0, Mariana.

(2019). La vida social de las cosas. Tramas policiales y judiciales en la construcción de un objeto museable (El caso del blindex de Perón). In: Mariana Sirimarco (Comp.); Narrar el oficio. Los museos de las fuerzas de seguridad como espacios de ficciones fundadora. Buenos Aires, Editorial Biblos, p.163-198.

DEL CASTILLO TRONCOSO, Alberto.

(2015). Fotografía y memoria en la dictadura argentina (1976-1983). Entrevista con Eduardo Longoni. Secuencia, n.95, p.215-258.

DIDI-HUBERMAN, Georges.

(2009). La imagen superviviente. Historia del arte y tiempo de los fantasmas según Aby Warburg. Madrid, Abada Editores.

(2004). Imágenes pese a todo. Memoria visual del Holocausto. Barcelona, Editorial Paidós.

DUBOIS, Philippe.

(1986). El acto fotográfico. De la representación a la recepción. Barcelona, Editorial Paidós.

COMAROFF, Jean y COMAROFF, John.

(2004). Criminal obsessions, after Foucault: postcoloniality, policing, and the metaphysics of disorder. Critical Inquiry, vol.30, n.4, p. 800824. 
ESCOLAR, Diego.

(2019). El museo del olvido: apuntes sobre la reconstrucción de la imagen institucional de la Gendarmería Nacional Argentina, 2001-2017. In: Mariana Sirimarco (Comp.); Narrar el oficio. Los museos de las fuerzas de seguridad como espacios de ficciones fundadora. Buenos Aires, Editorial Biblos, Buenos Aires, p.139-162.

(2017). Gendarmería: Los límites de la obediencia. Buenos Aires, Editorial SB.

ESCUDERO, Eduardo.

(2020). Memoria y dictadura: el Museo de la Lucha contra la Subversión en Buenos Aires y en Córdoba, para exhibir la superioridad del bien contra el mal. In: Marta Philp y Eduardo Escudero (Comps.); Usos del pasado en la Argentina contemporánea: memorias, instituciones y debates. Córdoba, Centro de Estudios Avanzados y Editorial de la Universidad Nacional de Córdoba, p.181-198.

FELD, Claudia.

(2014). Fotografía, desaparición y memoria: fotos tomadas en la ESMA durante su funcionamiento como centro clandestino de detención. Nuevo Mundo Mundos Nuevos, p.1-24.

(2010). Imagen, memoria y desaparición: una reflexión sobre los diversos soportes audiovisuales de la memoria. Aletheia, vol.1, n.1, p.1-16.

FORTUNY, Natalia.

(2014). Memorias fotográficas: imagen $y$ dictadura en la fotografía argentina contemporánea. Buenos Aires, La Luminosa.

GAMARNIK, Cora.

(2017). La imagen de la 'subversión': cómo se construyó la imagen del enemigo (1976-1979). Sudamérica, n.7, p.19-52.

(2016). El fotoperiodismo y la guerra de Malvinas: una batalla simbólica. In: John Mrazy Ana María Mauad (Orgs.); Fotografía e historia en América Latina. Montevideo, Centro de Fotografía de Montevideo, p.225-256.
(2015). La fotografía de prensa durante la guerra de Malvinas: la batalla por lo (in)visible. Páginas, vol.7, n.13, p.79-117.

(2013). La fotografía irónica durante la dictadura militar argentina: un arma contra el poder. Discursos fotográficos, vol.9, n.14, p.173-197.

(2012). Fotografía y dictaduras: estrategias comparadas entre Chile, Uruguay y Argentina. Nuevo Mundo Mundos Nuevos, s/d.

(2011). Acciones e imágenes de lo fotorreporteros durante la dictadura argentina. In: VI Jornadas de Jóvenes Investigadores. Buenos Aires, Instituto Gino Germani, Universidad de Buenos Aires, p.1-22.

(2010). La fotografía como instrumento político en Argentina: análisis de tres momentos clave". In: VI Jornadas de Sociología de la UNLP. La Plata, Universidad Nacional de La Plata, p.1-18.

GORDILLO, Gastón.

(2014). Rubble. The afterlife of destruction. Durham \& London, Duke University Press.

KOPYTOFF, Igor.

(1991). La biografía cultural de las cosas: la mercantilización como proceso. In: Arjun Appadurai (Ed.); La vida social de las cosas. Perspectiva cultural de las mercancías. México, Grijalbo, p.89-122.

LANGLAND, Victoria.

(2005). Fotografía y memoria. In: Elizabeth Jelin y Ana Longoni (Comps.); Escrituras, imágenes y escenarios ante la represión. Madrid/Buenos Aires, Siglo Veintiuno Editores, p.87-90.

LARRALDE ARMAS, Florencia.

(2015). Las fotos sacadas de la ESMA por Victor Basterra en el Museo de Arte y Memoria de La Plata: el lugar de la imagen en los trabajos de la memoria de la última dictadura militar argentina. Un estudio de caso. Centro de Estudios en Diseño y Comunicación, n.54, p.79102. 
MARCOS, Dolores.

(2005). Liderazgos autoritarios en el noroeste argentino: el caso Bussi en Tucumán. Reflexión Política, vol.7, n.13, p.42-58.

MELONI GONZALEZ, Carolina y ZURITA, Ruy Diego. (2018). Biopolítica de la subversión: el museo como dispositivo de invención, construcción y mostración del enemigo. El caso de la Jefatura Central de Policía en Tucumán. Contracorriente, vol.15, n.2, p. 220-244.

MENDIARA, Irina.

(1999). Las fotografías de archivo como datos culturales. Las imágenes del Hotel de los Inmigrantes. In: III Reunión de Antropología del Mercosur. Misiones, Universidad Nacional de Misiones. Mimeo.

MRAZ, John.

(2003). ¿Qué tiene la fotografía de documental? Del fotoperiodismo dirigido al digital. Disponible en: http://v1.zonezero.com/magazine/articles/m $\mathrm{raz} / \mathrm{mraz01sp}$. html. Consultado el 8 de Agosto de 2021.

NEMEC, Diego.

(2019). Pueblos de la "guerra". Pueblos de la "paz". Los pueblos rurales construidos durante el "Operativo Independencia" (Tucumán, 19761977). San Miguel de Tucumán, EDUNT.

RANCIERE, Jacques.

(2013). El espectador emancipado. Buenos Aires, Manantial.

RINESI, Eduardo.

(2019). Restos y desechos. El estatuto de lo residual en la política. Buenos Aires, Caterva Editorial.

RODRIGUEZ, Laura Graciela.

(2010). Políticas educativas y culturales durante la última dictadura militar en Argentina (19761983). Revista Mexicana de Investigación Educativa, p.1251-1273.

ROBBEN, Antonius.

(2008). Pegar donde más duele. Violencia política y trauma social en Argentina. Barcelona, Anthropos Editorial.
RUFER, Mario.

(2018). La memoria como profanación y como pérdida: comunidad, patrimonio y museos en contextos poscoloniales. A contra corriente, vol.15, n.2, p.149-166.

SALVI, Valentina.

(2012). De vencedores a víctimas. Memorias castrenses sobre el pasado reciente en Argentina. Buenos Aires, Editorial Biblos.

SCHINDEL, Estela.

(2016). La desaparición a diario. Sociedad, prensa y dictadura (1975-11978). Villa María, Eduvim.

SCHUFFER MENDOZA, Cynthia Pamela.

(2019). La imagen translúcida del Estadio Nacional. Políticas de la luz en las representaciones de la catástrofe chilena. Clepsidra, vol.6, n.11, p.92-109.

SIRIMARC0, Mariana.

(2020). Las cosas que recuperamos en combate. Exhibición de trofeos de guerra en la Córdoba de la subversión. Corpus. Archivos virtuales de la alteridad americana, vol.10, n.1, p.1-6.

(2019a). Presentación. Museos y fuerzas de seguridad en la Argentina. In: Mariana Sirimarco (Comp.); Narrar el oficio. Los museos de las fuerzas de seguridad como espacios de ficciones fundadora. Buenos Aires, Editorial Biblos, p.9-27.

(2019b). Las huellas de lo borrado. Muerte, guerra y restos corporales en los Museos de la Subversión. In: Mariana Sirimarco (Comp.); Narrar el oficio. Los museos de las fuerzas de seguridad como espacios de ficciones fundadora. Buenos Aires, Editorial Biblos, p.225-282.

(2014). La cosa y la palabra. Relato y emocionalidad en un museo policial. Revista del Museo de Antropología, vol.7, n.1, p.177-188.

SONTAG, Susan.

(2006). Sobre la fotografía. México, Alfaguara. 
THOMAS, Nicholas.

(1991). Entangled objects: exchange, material culture and colonialism in the Pacific. Cambridge, Harvard University Press.

ULANOVSKY, Lucía.

(2009). Fotografía de prensa y el Cordobazo.

Entre tradición y modernización de los tratamientos fotográficos. Revista Chilena de Antropología Visual, n.14, p.42-66.

\section{Recebido em}

outubro de 2021

\section{Aprovado em}

dezembro de 2021 